\title{
Market Reaction On Changes In Corporate's Name On The Indonesia Stock Exchange
}

\author{
Heriyanto and Candra Astra Terenggana \\ Fakultas Bisnis dan Akuntansi \\ Universitas Katolik Musi Charitas, Palembang \\ Email: heriyanto@ukmc.ac.id,candra_astra@ukmc.ac.id
}

\begin{abstract}
The market reaction on changes in corporate's name on the Indonesia Stock Exchange. This study tried to investigate empirically market reaction over the announcement of corporate name changes of companies on the Indonesia Stock Exchange. The market reaction is measured by using abnormal return with a single index model approach. The database of corporate name change announcements on the Indonesia Stock Exchange has obtained from an annual fact book report. The sample of this study consists of the companies that make a name change from 2005 to 2017. Hypothesis test uses one sample t-test. This research's result proves that there was a positive and significant market reaction to the corporate name change announcement. Moreover, This research's result shows that there was a positive and significant reaction on the corporate name change announcement which is included on major change while at the corporate name change announcement which included on minor change there was no significant market reaction.
\end{abstract}

Keywords: Abnormal Return, Corporate Name Changes, Minor, Major.

\section{INTRODUCTION}

The company name has a function as an organizational identity and is used as a strategic tool in a company. The name of the company is an individualistic element of company communication to the market. (Bae and Wang, 2012) in his research suggested that the use of company names is related to the valuation of company shares by investors and the research found that companies that use the name (word) "China" obtain a greater stock return than companies that do not use the name (word) "China". His research is also using a sample of companies based in China but shares are traded on US exchanges. And the result of his study indirectly indicated that company names influence investor investment decisions.

Over time being, it was discovered that some companies made changes to their names. (Bosch and Hirschey, 1989) stated that the reason for creating a new image of the company for stakeholders was the main motivation for the company to make a name change. The other reason for companies to change names according to (Bosch and Hirschey, 1989) is that the company would like to set a better business focus on several business sectors, to reflect changes in the company's product line, to prevent market "confusion" over the company's image compared to competitors, to reflect the restructuring process carried out by the company, to reflect diversification strategies 
carried out by the company, or to eliminate the old image of the company that is considered obsolete.

Furthermore, (Bosch and Hirschey, 1989) revealed that cases of the name change are concentrated in the economic sector (business) which tends to be dynamic or in a relatively stable economic sector but undergoing quite dramatic changes. These companies include companies in the financial, manufacturing and energy and technology sectors. The company decided to make a name change in hopes of having a positive impact on the company's stakeholders. If a company changes its name, this will be a major strategic action that will usually be related to costs (the company will ensure that the positive impact (benefits) of the name change is greater than the costs borne). This fee is related to communication with various stakeholders and intangible costs related to replacing the company name. In addition, the company's name change decision will have a direct impact on people's perceptions of the company's image in the market both regarding economic and non-economic aspects.

According to (Bosch and Hirschey, 1989), the company's name change policy showed the investment policy efforts made by the company on intangible capital by the company to change people's views related to the company's image so far. Based on this thinking, the researcher suspects that there is a market reaction around the date of the announcement of the company's name change as a form of market response to the company's investment policy on intangible assets.

From figure 1 data can be seen every year there are companies listed on the Indonesia Stock Exchange to change the name of the company (an average of about 12 cases of company name changes per year). The total cases of company name changes from 2005-2017 were 152 cases. The name change made by the company can have a negative impact on the company, one of which is the loss of the company's goodwill in the form of name recognition and company image in the past. In addition to the negative impact of the change of name certainly has a positive impact on the company. When the company experiences financial problems (financial distress), the name change can be a reason for the company to improve economic conditions (negative sentiment) because it affects the company's image or company brand.

\section{Number of Case Changes in Company Name}

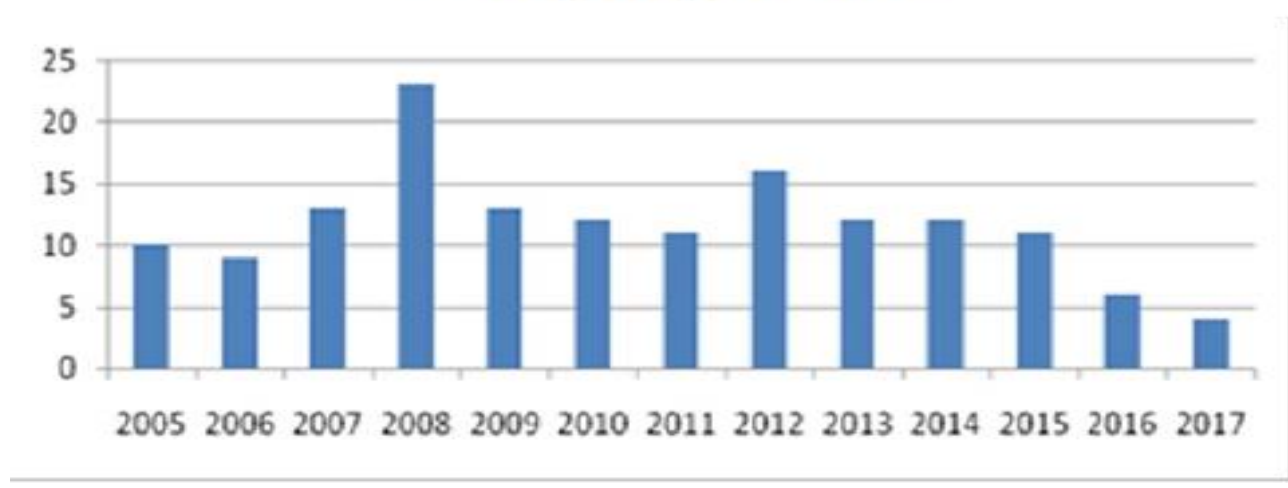


Figure 1. Number of companies that changed their names on the IDX from 2005 - 2017 Source: Data is processed from the annual fact book period $2005-2017$

The economic condition of a company can be seen from changes in the value of the company which can be reflected in the stock price. The stock price is determined by the condition of a company, if the condition of the company improves, the stock price will rise. Changes in prices can make changes in the behavior of investors to buy or sell their shares. The company's stock price is influenced by various factors, one of which is information entering the capital market related to company policy. This information can be in the form of financial or non-financial information. Change in the company name is non-financial information that is carried out as a form of corporate action. Name changes made by companies can influence investor investment decisions. Investors can react positively or negatively depending on the reason the company changed the name of the company. If the investor's reason is a good restructuring (prospect), investors tend to react positively while if the reason for the company name change is to improve the company's reputation because certain problems such as legal violations, certain investors will tend to react negatively because they are considered negative issues. (Mak, 2016) in his research found that a market reaction to the announcement of the refocusing announcement. Specifically, (Mak, 2016) indicated that investor reactions are highly dependent on predictions (expectations) of investors on the company's prospects in the future.

According to (Apriolita et al., 2011) there are several motives (reasons) for companies to make a name change, one of which is to revive a failed company. Usually, companies that fail in restructuring efforts will take a name change policy with the aim of "installing" the company's new identity. This strategy is expected to have a positive impact on the company in the future. (Kalaignanam and Bahadir, 2013) proved that the biggest market reaction occurs when the company changes the name of the company together with the restructuring process within the company compared to if the company only changes the name of the company or only restructures. Also, they stated that changes in company names accompanied by restructuring are considered as a form of the company's commitment to improving the company's prospects in the future (not just as cosmetics). Investors will respond positively to changes in company names. This positive reaction can be seen from the increase in stock prices or the volume of trading in the company's shares.

(Kashmiri and Mahajan, 2015) in their research proved that companies have a strong marketing influence and invest in marketing activities, and have high marketing capabilities will tend to cause companies more potential to make name changes. The results of the study of (Neelem and Aman, 2017) showed that there is an abnormal return (as a proxy for a positive market reaction) around the date of the name change. (Karpoff and Rankine, 1994) in his research also proved the same results. Contradictory to the result by (Josev et al., 2004) which proved that the market generally reacts negatively to information on company name changes and is increasingly prominent in the case of companies that make major company name changes (changes in company names that are very different from the first name). (Kot, 2011) in his research gave examples of changes in names included in minor changes if the company only made a few name changes, for example, e2-Capital (Holdings) Limited to E2-Capital (Holdings) Limited. Meanwhile, for major name changes, (Kot, 2011) explained that the company made a significant name 
change, for example, Innovative International (Holdings) Limited to become Gorient (Holdings) Limited.

(Bosch and Hirschey, 1989) in his research stated that the result of the research is related to the impact of changes in the name of the company on stock prices are relatively diverse. In fact, previous researchers such as (Howe, 1982) found that changes in company names did not have an impact on changes in stock prices. Researchers in Indonesia such as (Apriolita et al., 2011) as well (Octaviani, 2013) found that the market did not react to the announcement of changes in company names. In their research, (Bosch and Hirschey, 1989) mentioned that the impact of changes in company names on stock prices is strongly related to other events experienced by companies around the announcement date and is considered to have a material impact on the company's stock price (it is necessary to control other corporate actions when discussing name changes company). In addition, their research is focused more on cases of company name changes that are considered as a signal in the future carried out by company management to make fundamental changes to company programs. In their research stated that segregate groups of companies based on categories of company name changes such as (names change in major or minor, and change in company name involves a restructuring process or not). The result of the study from (Bosch and Hirschey, 1989) proved that the market reacts positively to the announcement of changes in company names. The positive reaction was more significant (greater) for companies that made a name change due to major restructuring and name change processes.

Other studies such as (Mathuva et al., 2016) examined the effect of company name change policies on the company's long-term financial performance. In their research, it is proved that the company's name change policy has a positive impact on the company's long-term financial performance which is proxied by return on assets (ROA) and net profit margin (NPM) variables.

Previous research related to the same topic used a relatively short period of 2 years (Apriolita et al., 2011) as well (Octaviani, 2013). In addition, studies conducted in Indonesia did not test market reactions to announcements of company name changes based on major and minor name change categories. These researches improve the shortcomings of previous studies in Indonesia by extending the research period and testing market reactions to announcements of company name changes in minor and major name change groups.

\section{THEORETICAL REVIEW}

Signaling Theory. According to (Josev et al., 2004), the economic signaling explained that there is information asymmetry in which managers (insiders) have more information than shareholders related to the company's prospects in the future. In this condition, managers have an incentive to take an action (decision) that is informative and reliable by investors in the capital market to maximize their welfare. In the context of this research, the information in question is one of them is the change of name of the company. Furthermore, (Josev et al., 2004) in his research stated that information on company name change provides a strong signal to investors related to the company's focus and future orientation of the company. Because the effort to change the name of the company 
requires costs such as legality and accounting costs, advertising costs, and the possibility of losing market share due to changes in the company's image, the company must also consider the benefits obtained from the name change. Conceptually, the company will make a name change with the belief that the company will get benefits that exceed the costs incurred from the name change policy. Therefore, information on changes in the name of the company allegedly has positive information content. Meanwhile, (Tadelis, 1999) stated that the concept of thinking behind the information content of a company name change is that the change in the company name is based on efforts to shape the company's reputation. Changes in company names are considered as an effort to bring an understanding of images that are more easily known (popular) from the company to the public. (Green and Russell, 2013) proved that the use of company names that are more familiar (popular), easy to remember, has a greater share distribution (broad), high trading transaction volume, low trade transaction costs, and company valuation ratios high. The company's name change policy can be considered as the company's investment policy on intangible assets because, in the process of deciding to change the name of the company, of course, the company takes into consideration the comparison of benefits and costs of the policy.

The hypothesis of Efficient Market. According to (Tandelilin, 2010), a capital market is stated to be efficient if the price of securities has reflected all the information in the capital market. In the financial sector itself, the context of efficient capital markets is mostly reviewed from the information (Informational Efficient Market) point of view. In his research also revealed that the concept of efficient capital markets is divided into three levels, namely weak form efficient markets, semi-strong efficient markets, and strong form markets.

Capital markets are stated to be efficient in the weak form if all past information reflects current securities prices. Based on this concept, past information (such as stock prices, trading volume, and past events) cannot be used to predict future price changes. The capital market is stated to be efficient in the form of a half-strong if all published information (corporate actions and other events published and can have a material impact on the company's cash flows in the future) has already reflected the current security prices. Meanwhile, capital markets are mentioned to be efficient in the form of strong if all information, both historical, published information, as well as unpublished information can reflect current securities prices.

The motivation for Changing Company Name. The company name reflects the image, identity or reputation of the company itself. On the way, companies are sometimes found to change company names. According to (Bosch and Hirschey, 1989) it is like the company would like to set a better business focus on several business sectors, to reflect changes in the company's product line, to prevent market "confusion" over the company's image compared to competitors, to reflect the restructuring process carried out by the company, to reflect the diversification strategies carried out by the company, or to eliminate the old image of the company that is considered obsolete. This opinion is in line with other researchers who stated the motivation of companies to change names due to 
mergers and acquisitions of (Kot, 2011), company diversification, and changes in business focus by (Karpoff and Rankine, 1994).

Specifically, (Bosch and Hirschey, 1989) revealed that cases of the name change are concentrated in the economic (business) sector which tends to be dynamic or in the relatively stable economic sector but experiences quite dramatic changes. These companies include companies in the financial, manufacturing and energy and technology sectors.

Market reaction to the Announcement of Changes to Company Name. Changing the name of the company is a form of the company's efforts to build a new image that is more easily understood by the community. There are a number of reasons that explain the company making a name change, such as mergers and acquisitions, changes in the company's product line, business diversification, the company focus on certain businesses, and so on. Behind these reasons, efforts to change the name of the company are seen as having information for the public. Specifically, the action of changing the name of the company reflects the signal that the company wants to convey related to the condition (potential) and the direction of the company's orientation in the future. Changes in company names are also considered as a form of company investment policy on intangible assets aimed at increasing the prosperity of stakeholders in the company. Before making an effort to change the name of the company, company management certainly ensures in advance that the benefits obtained from efforts to change the name of the company must be greater than the costs that must be borne. Related to this, efforts to change the name of the company are seen as a sign of the company's belief in the prospects and direction of the company's orientation in the future.

Based on this, Hypothesis 1 is formulated: There is a positive market reaction to the announcement of company name changes.

Market reaction to Changes in Minor and Major Names. (Mase, 2009) in their research grouped company name changes into radical name changes (amendments) and amendments to companies in the UK stock exchange. Specifically, (Mase, 2009) found that there was a significant positive market reaction to radical name changes, whereas in a change in the name some did not find a significant market reaction. (Kot, 2011) in his research classified the company name changes into minor name changes and major name changes. In his research explained that name changes were included in minor changes if the company only made a few name changes, for example, e2-Capital (Holdings) Limited to E2-Capital (Holdings) Limited. Meanwhile, for major name changes, (Kot, 2011) explained that the company made a significant name change, for example, Innovative International (Holdings) Limited to become Gorient (Holdings) Limited. The result of the study from (Kot, 2011) showed that there was a significantly greater positive reaction to the announcement of major company name changes than the announcement of minor name changes. This showed that investors view major name changes as having more information content related to the company's efforts to clarify the company's orientation (focus) in the future. Based on this, Hypothesis 2 is formulated: there is a more positive market reaction to the announcement of major name changes compared to minor name changes. 
Previous research. Some previous studies have examined investors' reaction to the announcement of changes in company names. (Bosch and Hirschey, 1989) in their research proved that the market reacts positively to the announcement of changes in company names. The positive reaction was more significant (greater) for companies that made a name change due to major restructuring and name change processes. (Josev et al., 2004) in his study showed that in general there was a negative market reaction to the announcement of company name changes and increasingly prominent in the case of major company name changes. (DeFanti and Busch, 2011) found that a more positive and significant reaction occurred in major company name changes compared to minor changes. (Karim, 2011) in his study found that changes in the name of the company had a positive impact on the prosperity of stock investors, where this was seen from the existence of positive abnormal returns on announcements of name changes. (Biktimirov and Durrani, 2017) in their research found that changes in the name of the company in the capital market in Toronto received a positive reaction from investors.

(Lee, 2001) in his research on market reactions to changes in company names by adding ".com" to prove there was a positive and significant market reaction. Specifically, (Lee, 2001) found that a greater positive reaction occurs in cases of name changes accompanied by a consistent change strategy (not just an image change). (Lin et al., 2016) in his research on market reactions to changes in company names relating to the addition or subtraction of words relating to "oil" indicated that investors reacted to the announcement. Specifically, (Lin et al., 2016) found that companies in the United States capital market that make changes to their names by adding words related to "oil" get positive reactions while companies that eliminate words related to "oil" get negative and significant reactions.

$(\mathrm{Wu}, 2010)$ in his research examined the relevance of the company's past performance with changes in company names and the impact of changes in company names on the company's abnormal return on shares. (Wu, 2010) proved that companies that have stock performance, accounting financial performance, media coverage, and better brands tend to make name changes so that company names are more closely related to corporate brands so far, while companies with stock performance, accounting financial performance, and worse media coverage tends to make radical (significant) name changes. Furthermore, $(\mathrm{Wu}, 2010)$ proved that the market's positive reaction to name changes is related to the company's brand, while the name change radically experiences negative market reactions.

(Kashmiri and Mahajan, 2015) in their study showed that there was a significant market reaction to the change in the company name. Specifically, they found that greater profits occur in shares of companies that control the broad scope of marketing, investment in marketing is high, marketing capabilities are higher. In addition, also (Kashmiri and Mahajan, 2015) found that companies that make changes to the name in order to strengthen the company's brand and actively communicate changes in business scope (due to name changes) tend to get higher stock returns.

(Mathuva et al., 2016) in its research on the impact of the policy of changing the name of the company on the company's financial performance proves that changes in the name of the company have a positive effect on the company's financial performance. 
Specifically, the positive impact of financial performance can be seen on average 4 years after the change in the company name.

(Apriolita et al., 2011) and (Octaviani, 2013) in their research using company name change data on the IDX showed that the market did not react to the announcement of company name changes. (Karbrahi et al., 2004) in his research regarding the market reaction to company name changes in Malaysia by distinguishing bankrupt and nonbankrupt companies proving the market did not react to changes in company names. (Karbrahi et al., 2004) explained that company name changes that have a significant impact only on companies that carry out restructuring or organizational changes that direct the company to the clarity of future prospects.

\section{METHODOLOGY}

This research is quantitative research. This study intends to test hypotheses related to market reactions to the announcement of company name changes on the IDX. This study uses a company name change database from an annual fact-book data source to confirm efficient capital market signaling theory and hypotheses with respect to the information content of company name change announcements.

The population of this study includes all companies on the Indonesia Stock Exchange who made changes to the name. The sample selection uses a purposive sampling method with criteria including companies on the IDX during 2005-2017, companies have complete daily closing stock price data during the estimation period and window period, the company does not announce or conduct other corporate actions that have a material impact on the company's stock price such as stock-split, rights issue, dividend distribution, etc., and active companies are transacted for at least 30 active trading days from the entire estimated period (100 days). This provision refers to research (Hardjanto, 2004).

The number of companies that changed company names during the period 2005 2017 was 152 companies. As for sample criteria selection, 3 companies do not have complete daily stock price data, 63 companies share prices are not active in trade, and there are 5 companies that do other corporate actions (such as announcements of financial statements, dividends, stock splits, right offers, and others) around the date of the announcement of the company name change. Based on table 1, it can be seen that the number of the final sample of the study was 81 companies.

Table 1. Obtaining Research Samples

\begin{tabular}{c|c}
\hline Initial sample amount & 152 \\
\hline Stock price data is not completely available & $(3)$ \\
\hline $\begin{array}{c}\text { Stock price data are not actively traded } \\
\text { during the estimation period }\end{array}$ & $(63)$ \\
\hline Do other corporate actions & $(5)$ \\
\hline Final Samples & $\mathbf{8 1}$
\end{tabular}

Source: ( Data processed, 2019) 
Furthermore, the study sample was divided into 26 companies classified as minor changes and 55 companies included in the major changes.

This study uses secondary data in the form of data on daily closing prices of company shares around the date of the announcement of the company name change during the period 2005-2017.

Daily closing stock price data is taken from www.finance.yahoo.com or Bloomberg finance database. For daily closing stock price data that cannot be obtained at www.finance.yahoo.com, the data is provided by TICMI. Data on company name changes were obtained from the annual fact book report on the www.idx.co.id site. Corporate data action, such as earnings announcements, stock dividends, bonus shares, stock splits, rights issues, tender offers, mergers and acquisitions, and other financial information obtained from the PDBE UGM database, the Bloomberg database of Gadjah Mada University (BNI46 Financial Market Update), and database www.ksei.co.id. This is related to efforts to avoid the confounding effect.

This study uses documentation techniques in data collection. Data sources in the form of information or reports from the Indonesia Stock Exchange (annual fact book report for the period 2005 - 2017) or website www.idx.co.id, www.finance.yahoo.com and www.ticmi.co.id.

The dependent variable is the abnormal return. Abnormal return is the difference between the actual return and the expected return, which is stated as follows:

$$
R T N_{i, t}=R_{i, t}-E\left(R_{i, t}\right)
$$

Note:

$\mathrm{RTNi}, \mathrm{t}=$ return is not fair share with $\mathrm{i}$ on day $\mathrm{t}$

$\mathrm{Ri}, \mathrm{t}=$ actual return for stock $\mathrm{i}$ on day $\mathrm{t}$

$\mathrm{E}(\mathrm{Ri}, \mathrm{t})=$ expected return for stock $\mathrm{i}$ on day $\mathrm{t}$

Actual return is a return that occurs on day $t$ which is the difference in current prices relative to the previous price, calculated by the formula:

Note:

$$
R_{t, t}=\frac{P_{t}-P_{t-1}}{P_{t-1}}
$$

Rit $=$ actual return for stock $\mathrm{i}$ on day $\mathrm{t}$

$\mathrm{Pt}=$ closing stock price on day $\mathrm{t}$

$\mathrm{Pt}-1=$ closing stock price on day $\mathrm{t}-1$

Therefore, the expected return is the return expected by investors. Expected returns are calculated using the single index model method. Abnormal returns are an indicator of market reaction to the announcement of company name changes.

Date of announcement date company name change is the date when the company announced a change of name on the Indonesia Stock Exchange. The event window period 
is 5 days before, during, and 5 days after the date of the announcement of the company name change. The estimated period in this study is 100 days, starting from t-105 to t- 6 . (Tandelilin, 2010) suggested that in the test of the case of event study, ideally, the minimum sample size would be 30 companies with an estimated period of 100 days to 200 days of observation.

The following stages are to obtain the company's abnormal stock returns: (1) Calculate daily individual stock profits for each period, (2) Calculate the daily market profits with the formula:

Note:

$$
R m t=\frac{P_{m t}-P_{m t-1}}{P_{m t-1}}
$$

$\mathrm{Rmt}=$ return of $\mathrm{JCI}$ on day $\mathrm{t}$

Pmt $=$ IHSG value on day $t$

Pmt-1 = IHSG value on day $\mathrm{t}-1$ (previous period)

(3) Calculating $\alpha$ and $\beta$ stocks using regression during the estimation period.

$$
\begin{aligned}
R T N_{i, t} & =R_{i, t}-E\left(R_{i, t}\right) \\
R_{i t} & =\alpha_{i}+\beta_{i} R_{m t}+e_{i t}
\end{aligned}
$$

Note:

Rit = company stock return $\mathrm{i}$ in the estimated period $\mathrm{t}$

$\mathrm{Rmt}=\mathrm{IHSG}$ return in the estimated period $\mathrm{t}$

$\alpha \mathrm{i}=$ intercept company stock $\mathrm{i}$

$\beta i=$ company stock slope (beta) coefficient $i$

eit $=$ error term of securities $i$ in the estimated period $t$

(4) Calculating Abnormal Return by Using Single Index Model:

$$
A R_{i t}=R_{i t}-\left(\alpha_{i}+\beta_{i} R_{m t}\right)
$$

Information:

ARIT $=$ abnormal return on company stock ion day $\mathrm{t}$

$\mathrm{Rit}=$ actual return for company shares $\mathrm{i}$ on day $\mathrm{t}$

$\mathrm{Rmt}=$ return of JCI on day $\mathrm{t}$

The next stage is related to the testing process of significance (cumulative) abnormal return

(5) Calculating Cumulative Abnormal Return 


$$
C A R_{i t}=\sum_{t=-5}^{t=+5} A R_{i t}
$$

Information:

CARit $=$ cumulative abnormal return company $\mathrm{i}$ on day $\mathrm{t}$

ARIT $=$ abnormal return on company stock $\mathrm{i}$ on day $\mathrm{t}$

(6) Calculating Average Cumulative Abnormal Return

Note:

$$
A C A R_{t}=\frac{\sum_{i=1}^{k} C A R_{i t}}{k}
$$

ACARt $=$ average cumulative abnormal return on days $\mathrm{t}$

CARit $=$ cumulative abnormal return on company stock $\mathrm{i}$ on day $\mathrm{t}$

$\mathrm{k}=$ number of company shares affected by announcements of company name changes

(7) Calculating the significance of Cumulative Abnormal Return

$$
S C A R_{i t}=\frac{C A R_{i t}}{K S E i}
$$

Note:

SCARit $=$ standardized cumulative abnormal return company $\mathrm{i}$ day $\mathrm{t}$

CARit $=$ cumulative abnormal return on company stock $\mathrm{i}$ on day $\mathrm{t}$

$\mathrm{KSEi}=$ estimated standard error for company shares $\mathrm{i}$

The estimation standard error is determined based on the standard deviation of company stock returns i from its standard value (the value of the company's stock return i) during the estimation period calculated by:

Note:

$$
K S E_{i}=\frac{\sqrt{\sum_{t=t 1}^{t 2}\left(R_{i t}-\bar{R}_{i}\right)^{2}}}{T i-2}
$$

KSEi = estimated standard error for company shares $\mathrm{i}$

Rit $=$ actual return of company stock $\mathrm{i}$ on $\mathrm{t}$ day in the estimated period

$=$ average company stock return during the estimation period

$\mathrm{Ti}=$ number of days in the estimation period, ie from day t 1 to day

After the SCARit value is obtained, that is the value of $t$ count for each cumulative abnormal return of company stock $i$ on day $t$, then calculated the SCARt value which is the value of $t$ count for each day $t$ in the window period. 


$$
\operatorname{SACAR}_{t}=\frac{1}{\sqrt{k}} \sum_{i=1}^{k} S C A R_{i t}
$$

Information:

SACARt $=$ standardized cumulative abnormal return on day $\mathrm{t}$

SCARit $=$ standardized cumulative abnormal return of company stock $\mathrm{i}$ on day $\mathrm{t}$

$\mathrm{k}=$ number of company shares

Data analysis technique uses one sample t-test. Statistics test for each period using t-count which aims to see the significance of abnormal returns in each period of events.

\section{RESULT AND DISCUSSION}

Descriptive Statistics Analysis. Table 2 showed that based on the overall study sample, the sample name changes included in minor and major changes, the highest average cumulative abnormal return on $\mathrm{t}-1$ to t 0 the announcement of changes in company names is $2.27 \%,-0.47 \%$ and $3.56 \%$ respectively. Specifically average cumulative abnormal return in the case of changes in company names included in major changes is higher than average cumulative abnormal return in cases of company name changes included in minor changes. The highest cumulative abnormal return standard deviation in all samples and minor change samples occurred at $\mathrm{t}-1-\mathrm{t}+5$ periods of company name changes with $14.57 \%$ and $11.34 \%$ respectively, while the highest cumulative abnormal return standard deviation in change samples major occurs on t- 1 to t0 period of company name change which is equal to $16.66 \%$.

Table 2. The Mean and Standard Deviation of Cumulative Abnormal Return on Announcement of Changes in Company Name on the IDX

\begin{tabular}{ccccccc}
\hline Periode & \multicolumn{2}{c}{ CAR (Full } & \multicolumn{2}{c}{ CAR (Minor) } & CAR (Major) \\
& \multicolumn{2}{c}{ Sample) } & & & & \\
\cline { 2 - 7 } & Mean & $\begin{array}{c}\text { Standar } \\
\text { Deviasi }\end{array}$ & Mean & $\begin{array}{c}\text { Standar } \\
\text { Deviasi }\end{array}$ & Mean & $\begin{array}{c}\text { Standar } \\
\text { Deviasi }\end{array}$ \\
$\mathbf{t ~ ( - 1 , 0 )}$ & $2,27 \%$ & $14,21 \%$ & $-0,47 \%$ & $5,93 \%$ & $3,56 \%$ & $16,66 \%$ \\
$\mathbf{t}(\mathbf{- 1},+\mathbf{1})$ & $2,10 \%$ & $12,33 \%$ & $-0,61 \%$ & $6,84 \%$ & $3,37 \%$ & $14,09 \%$ \\
$\mathbf{t}(-\mathbf{1},+\mathbf{5})$ & $1,43 \%$ & $14,57 \%$ & $-0,48 \%$ & $11,34 \%$ & $2,33 \%$ & $15,89 \%$ \\
\hline
\end{tabular}

Source: (data processed, 2019)

Analysis and Hypothesis Test. Table 3 and Table 4 showed the result of different tests using one sample t-test on the average cumulative abnormal return of the overall sample, minor change samples, and major change samples. Based on the results of data analysis in table 3 , in the overall sample, a significant $t$ count occurs at the cumulative abnormal return average $t-1$ up to $t+1$ period of company name change with $t$ count 1.876 greater than t table (critical) 1.66 (one tail with a level of $\alpha=5 \%$ ). Meanwhile, on t- 1 to t0 the period of change in company name value of $t$ count 1.353 is greater than table (critical) 
1.29 (one tail with a level of $\alpha=10 \%$ ). It supports hypothesis 1 in this study that there is a positive market reaction around the date of the announcement of the company name change.

Based on the results of data analysis in table 3, in the minor change sample, there is no significant $t$ value or smaller than the table (critical) of 1.71 (one tail with the level $\alpha=5 \%$ ) and 1.32 (one tail with a level of $\alpha=10 \%$ ). In a major change sample, a significant t count occurs at the average cumulative abnormal return $t-1$ to to and $t-1$ up to $t+1$ period of company name change with a value of $t$ count 2.235 and 2.699 greater than $\mathrm{t}$ table (critical) of 1.67 (one tail with a level of $\alpha=5 \%$ ) and 1.30 (one tail with a level of $\alpha$ $=10 \%$ ). The result of the test in table 4 supports hypothesis 2 which stated that positive market reactions occur more in cases of major name changes than minor name changes.

Table 3. The Result of Market Reaction Test by Using Full Sample

\begin{tabular}{ccc}
\hline \multicolumn{1}{c}{ Periode } & \multicolumn{2}{c}{$($ Full Sample $)$} \\
\cline { 2 - 3 } & $\begin{array}{c}\text { ACAR } \\
\text { (Standardized) }\end{array}$ & t count \\
$\mathbf{t}(\mathbf{- 1 , 0 )}$ & $10,63 \%$ & 1,353 \\
$\mathbf{t}(\mathbf{- 1 , + \mathbf { + 1 } )}$ & $12,04 \%$ & $\mathbf{1 , 8 7 6}$ \\
$\mathbf{t}(\mathbf{- 1 , + 5 )}$ & $5,15 \%$ & 1,226 \\
\hline Source: (data processed, 2019) &
\end{tabular}

Table 4. The Result of Market Reaction Test on Changes in Minor and Major Names

\begin{tabular}{ccccc}
\hline Periode & \multicolumn{2}{c}{$($ Minor $)$} & \multicolumn{2}{c}{ (Major) } \\
\cline { 2 - 5 } & ACAR & $\mathbf{t}$ & ACAR & t count \\
& (Standardized) & count & (Standardized) & \\
$\mathbf{t}(-\mathbf{- 1 , 0 )}$ & $-11,96 \%$ & $-0,862$ & $21,31 \%$ & $\mathbf{2 , 2 3 5}$ \\
$\mathbf{t}(\mathbf{- 1 , + 1 )}$ & $-6,94 \%$ & $-0,613$ & $21,01 \%$ & $\mathbf{2 , 6 9 9}$ \\
$\mathbf{t}(\mathbf{- 1 , + 5 )}$ & $-0,02 \%$ & $-0,002$ & $7,59 \%$ & 1,489 \\
\hline
\end{tabular}

Source: (data processed, 2019)

\section{DISCUSSION}

The result of the hypothesis test proved that there is a significant positive market reaction in the whole sample. This finding is consistent with the results of the study (Kot, 2011), (Bosch and Hirschey, 1989), (Horsky and Swyngedouw, 1987), (Koku, 1997), and (Karim, 2011) which proved that there is a reaction (positive impact) on value company for changes in company name. The result of the study showed that the market (investors) assumed that the company's name change strategy represents the company's belief that the benefits obtained from the company's name change decision outweigh the costs resulting from this decision. Changes in company names are considered as strategic policies taken by company management to bring the company's new focus (orientation) in the future to improve company performance. Furthermore, information on announcements of company name changes is considered as a signal (message) for the form of company management's 
confidence in the direction of the company's new orientation in the future. This proves that the hypothesis in this study is accepted. Meanwhile, the results of this study contradict the findings of (Josev et al., 2004), (Aprilolita et al., 2011), as well as (Oktaviani, 2013) which proved that there is no positive (reaction) impact on changes in company names.

Furthermore, based on table 4, the result of the test in minor and major name changes are indicated that a significant positive reaction to a major name change is greater than a minor name change. Major changes in company names are considered as strategic and radical changes that have an impact on efforts to improve the company's financial performance going forward. In accordance with the research of (Bosch and Hirschey, 1989) and (Kot, 2011), this study also proved that positive and significant reactions were greater in major name changes than minor name changes. Major changes are associated with name changes due to the company establishing a new orientation (focus) from the company, restructuring the company's organizational structure, changes in company management, and so on. Meanwhile, (Josev et al., 2004) and (Aprilolita et al., 2011) found the opposite results where the highest significant negative reaction was found in major name changes compared to minor name changes.

\section{CONCLUSION}

Based on the tests conducted, it was concluded that there was a positive and significant market reaction on the announcer of the change in the company name. Furthermore, a significantly greater positive market reaction occurs in major name changes and there is no significant market reaction to minor name changes.

The researcher realized that there were limitations to this study. Specifically, Research has not observed market reactions to company name changes based on reasons for name changes, such as mergers and acquisitions, restructuring, changes in business focus (line), revamping company reputation as conducted by research (Kot, 2011). This study also has not used a measure of company performance as a proxy for measuring the long-term impact of a company's name change policy. (Mathuva and Muthuma, 2016) used the measurement of long-term financial performance such as ROA and NPM. (Cole et al., 2015) in his research of the impact of name changes on insurance demand by using a variable income increase (premium) as a measure of financial performance. Further research can also consider the size of the company as a control variable (grouping of companies). (Gupta and Aggarwal, 2014) in their research proved that there are differences in market reactions to company name changes based on grouping the company's market capitalization. Based on this, further research should consider some of these things to develop future research results. Future studies can also use the 21-day research window period as suggested in the study (Peterson, 1989).

\section{REFERENCES}

Apriolita, Mayang; Gumanti, Tatang Ary; Swastika, dan Dwi Lusi Tyasing. (2011). Pengumuman Pergantian Nama Perusahaan dan Harga Saham di Bursa Efek Indonesia. Finance and Banking Journal. 13 (1): 62-76. 
Bae, Kee-Hong and Wang, Wei. (2012). What's in a "China" Name? A Test of Investor Attention Hypothesis. Financial Management, 41 (2): 429-455.

Biktimirov, Ernest N. and Durrani, Farooq. (2017). Market Reactions to Corporate Name Changes: Evidence From The Toronto Stock Exchange. International Journal of Managerial Finance. (13): 50-69.

Bosch, Jean-Claude dan Hirschey, Mark. (1989). The Valuation Effects of Corporate Name Changes. Financial Management, 18 (4): 64-73.

Cole, Casandra R., Fier, Stephen G., Carson, James M., dan Andrews, Demetra. (2015). The Impact of Insurer Name Changes on The Demand for Insurance. The Journal of Risk and Insurance. Vol. 82(1): 173-203.

DeFanti, Mark P. and Busch, Paul S. (2011). Image-Related Corporate Name Changes: Their Effect Upon Firm's Stock Prices. Journal of Brand Management, 19: 241-253.

Green, T. Clifton and Jame, Russell. (2013), Company Name Fluency, Investor Recognition, and Firm Value. Journal of Financial Economics. Vol. 109(3): 813834.

Gupta, Mohit dan Aggarwal, Navdeep. (2014). The Impact of Stock Name Change on Shareholder Wealth: Evidence From Indian Capital Markets. Journal of Management Research. Vol. 14(1): 15-24.

Hardjanto. (2004). Transfer Informasi Intra Industri atas Pengumuman Perubahan Dividen serta Pengaruh Tingkat Dividen Surprise Perusahaan Reporter, Ukuran Perusahaan Reporter, dan Tingkat Konsentrasi Perusahaan Reporter Terhadap Besarnya Transfer Informasi pada Perusahaan-Perusahaan yang Terdaftar di Bursa Efek Jakarta. Tesis S2 Program Pasca Sarjana Universitas Diponegoro.

Horsky, Dan; Swyngedouw, Patrick. (1987). Does It Pay To Change Your Company's Name? A Stock Market Perspective. Marketing Science. 6 (4): 320-335.

Howe, J. (1982). A Rose by Any Other Name? A Note on Corporate Nama Changes. The Financial Review, Vol. 17 (4): 271-278.

Josev, Thomas, Chan Horward, and Faff, Robert. (2004). What's in a Name? Evidence on Corporate Name Changes from the Australian Capital Market. Pacific Accounting Review, 16 (1): 57-76.

Kalaignanam, Kartik dan Bahadir, S. Cem. (2013). Corporate Brand Name Changes and Business Restructuring: Is The Relationship Complementary or Substitutive?. Journal of The Academy of Marketing Science. Vol. 41(4): 456-472.

Karbhari, Yusuf, Sori, Zulqarnain Mohamad, Mohamad, Shamsher. (2014). Shareholder Wealth Effects And Corporate Name Change: Evidence From Malaysia. Corporate Ownership \& Control, 2: 38-49.

Karim, Bicha. (2011). Corporate Name Change and Shareholder Wealth Effect: Empirical Evidence in The French Stock Market. Journal of Asset Management, 12(3): 203213.

Karpoff, J.M., Rankine, G. (1994). In Search of A Signaling Effect: The Wealth Effects of Corporate Name Changes. Journal of Banking \& Finance. 18: 1027-1045.

Kashmiri, Saim dan Mahajan, Vijay. (2015). The name's the game: Does Marketing Impact The Value of Corporate Name Changes?. Journal of Business Research, 68: 281-290. 
Koku, Paul Sergius. (1997). Corporate Name Change Signaling in The Service Industry. Journal of Service Marketing. 11 (6): 392-408.

Kot, Hung Wan. (2011). Corporate Name Changes: Price Reactions and Long-Run Performance. Pacific-Basin Finance Journal. 19: 230-244.

Lee, Peggy M. (2001). What's in a Name.com?: The Effects of '.com' Name Changes on Stock Prices and Trading Activity. Strategic Management Journal. Vol. 22 (8): 793804.

Lin, Hsiao-Mei, Fok, Robert (Chi-Wing), Yang, Shih-An, Chang, Yuanchen. (2016). The Wealth Effects of Oil-Related Name Changes on Stock Prices: Evidence From the U.S. and Canadian Stock Markets. Journal of International Financial Markets, Institutional \& Money, 40: 26-45.

Mak, Chun Yu. (2016). Do Market Predictions Affect Its Reaction to UK Listed Industrial Firms' Corporate Refocusing Announcements?. The British Accounting Review, 48: 464-478.

Mase, Bryan. (2009). The Impact of Name Changes on Company Value. Managerial Finance, Vol. 35 (4): 316-324.

Mathuva, David Mutua, Muthuma, Elizabeth Wangui, and Kiweu, Josephat Mboya. (2016). The Impact of Name Change on The Financial Performance of Savings and Credit Co-operatives in Kenya. Management Research Review, Vol. 39 (10): 12651292.

Neelam, Rani, and Aman, Asija. (2017). Signaling Power of Corporate Name Change: A case of Indian Firms. Global Journal of Flexible Systems Management, 18 (3): 173181.

Octaviani, Cristina. (2013). Reaksi Pasar Terhadap Pengumuman Perubahan Nama Perusahaan. Jurnal Keuangan dan Bisnis. Edisi Oktober.

Peterson, Pamela P. (1989). Event Studies: A Review of Issues and Methodology.Quarterly Journal of Business and Economics. 28 (3): 36-66.

Tadelis, S. (1999). What's in a Name? Reputation as a Tradeable Asset. American Economic Review. 89: 548-563.

Tandelilin, E. (2010). Portofolio dan Investasi Teori dan Aplikasi, Edisi Pertama. Kanisius: Yogyakarta.

Wu, YiLin. (2010). What's in a Name? What Leads a Firm to Change Its Name And What The New Name Foreshadows. Journal of Banking \& Finance. 34: 1344-1359. 